\title{
Tidal flats of recent origin: distribution and sedimentological characterization in the estuarine Cruces River wetland, Chile
}

\author{
Mario Manzano-Castillo ${ }^{1}$, Eduardo Jaramillo-Lopéteguii ${ }^{1}$ \& Mario Pino-Quivira ${ }^{1}$ \\ ${ }^{1}$ Institute for Earth Sciences, Faculty of Science, Universidad Austral de Chile \\ Valdivia, Chile \\ Corresponding author: Mario Manzano (mario.a.manzano.c@gmail.com)
}

\begin{abstract}
The sedimentary intertidal surfaces (tidal flats from here on) in coastal wetlands are globally recognized by their biological diversity and available ecosystem services. In Chile, these environments are mainly distributed between 30 and $41^{\circ} \mathrm{S}$ and associated with micro-tidal estuaries. The estuarine Cruces River Wetland (CRW) was formed by tectonic subsidence caused by the giant $9.5 M_{W}$ Valdivia earthquake in May 1960. The CRW is characterized by relatively uniform water quality conditions and tidal ranges and a significant increase of discharge and elevation of the water table concurrent with intense winter precipitations. The present study focuses on the presence and distribution of tidal flats in the CRW. It evaluates the spatio-temporal variability (April vs. December 2016) of texture and geochemical parameters ( $\mathrm{pH}$ and ORP (oxidation/reduction potential, ORP)) of surface sediments in six particular tidal flats located along the main channel of the Cruces River. Most of the tidal flats are located in the northern and southern sectors of the CRW. Those located in the middle and southern sectors of the study area exhibit denser coverage with vestigial tree trunks that evidence the former presence of marsh forests along the flooded shores. The texture of the studied sediments is dominated by sand $(0.063-2 \mathrm{~mm})$, followed by mud grain size fractions $(<0.063 \mathrm{~mm})$. The mud fraction is the only grain size showing significant differences between the studied tidal flats. Both the $\mathrm{pH}$ and ORP values vary significantly between sites and sampling periods. In general, ORP values were lower or negative in samples with higher mud and total organic matter contents collected mainly during both sampling times. These results set the first baseline for textural and basic geochemical characteristics of surface sediments from tidal flats in the Cruces River wetland. The database provides a primary tool for evaluating potential effects of possible alterations along the margins of the wetland, which is located in an area of the rapid development of forestry and industrial activities as well as urban expansion.
\end{abstract}

Keywords: estuarine wetlands; sedimentary tidal flats; sediment texture; southern Chile

\section{INTRODUCTION}

The sedimentary intertidal surfaces (tidal flats from here on) associated with coastal wetlands have been globally recognized by their great importance for the conservation of wild fauna and the supply, maintenance, and regulation of multiple ecosystem services (Miththapala, 2013; Murray et al., 2015). These include the regulation of carbon sinks (Thom et al., 2001), the control of flooding during tidal cycles (Healy et al., 2002), the enrichment of coastal waters via nutrient supply (Miththapala, 2013), and the availability of substrate for aquatic macrophytes (Neira et al., 2006) and benthic invertebrates that sustain the diet of aquatic herbivorous and carnivorous birds (Reise, 1985; Reise et al., 2010). Nonetheless, these tidal flat environments are highly vulnerable due to the environmental deterioration generated by urban expansion and associated industrial development (Barbier et al., 2011; Koh \& Khim, 2014; Bagdanaviciute et al., 2015).

Most of the tidal flats in Chile are located in coastal areas between 30 and $41^{\circ} \mathrm{S}$ and are mainly associated with micro-tidal estuaries in fluvial plains (Pino, 1994; Jaramillo et al., 2001). There are approximately 400 wetlands within this latitudinal range. Many of them are interconnected and directly linked to the characteristics 
and quality of waters that supply and maintain these shallow water bodies (Niering, 1985; Fariña \& Camaño, 2012).

The Cruces River wetland (CRW) is located at $\sim 40^{\circ} \mathrm{S}$ and formed by co-seismic continental subsidence (up to $2.5 \mathrm{~m}$, Plafker \& Savage, 1970) caused by the giant $9.5 M_{W}$ Valdivia earthquake in May 1960 (DeMets et al., 1990). As a result, the areas adjacent to the fluvial channel of the CRW, and previously occupied by agriculture, stock farming, and march forests, transformed into shallow-water or frequently flooded realms. These areas are currently characterized by the dense occurrence of Schoenoplectus californicus (C.A. Mey.) - an aquatic macrophyte knew as Junco or totora - tidal flats, and vestigial trunks attesting ancient forests that occupied the river banks before the subsidence.

The heterogeneous environment resulting from this major geomorphological transformation and subsequent reconversion of riparian habitats favored the occurrence of a great variety of macrophytes and aquatic birds (Ramírez et al., 1991; Schlatter et al., 1991, 2002; San Martín et al., 1993). These circumstances were fundamentally behind the incorporation of the wetland in 1981 into the list of internationally important wetlands entitled by the Ramsar Convention (www.ramsar.org), an international organization created to promote the conservation and sustainability of wetland environments around the globe. Nonetheless, the CRW has not stayed immune against anthropologically induced environmental perturbations. It is crowned by the 2004 environmental changes associated with the industrial activity of a pulp mill plant located in the wetland catchment area (Escaida et al., 2014). Most studies related to the CRW realm ecology are focused on ecosystem components that were notoriously affected by changes, for example, in water quality (Woelfl et al., 2006; Lagos et al., 2008; Schaefer \& Einax, 2010), aquatic macrophytes (Pinochet et al., 2005; Ramírez et al., 2006; Jaramillo et al., 2007; Marín et al., 2009; Palma et al., 2013), and water birds (Jaramillo et al., 2007; Lagos et al., 2008; González \& Fariña, 2013). Those research lines arose from the occurrence of those environmental changes, not as a particular intention to obtain integral knowledge about the physicochemical and biological structure of the wetland. The tidal flats appear as a particularly important component due to the great variety of ecosystem services they provide. Given these facts, the present study's main objectives are to analyze the occurrence and distribution of tidal flats in the CRW and to evaluate the spatio-temporal variability of the texture and essential geochemical characteristics $(\mathrm{pH}$ and oxidation/reduction potential, ORP) of sediments.
In case of environmental changes of global or regional character, our results will contribute to the gathering of basic knowledge in order to develop useful tools for future management strategies, including the manipulation, conservation, or restoration of tidal flats located in south-central Chile.

\section{MATERIALS AND METHODS}

\section{Study area}

The Cruces River wetland (CRW) is located just north of the city of Valdivia in southern Chile $\left(\mathrm{ca} .40^{\circ} \mathrm{S}\right)$ (Fig. 1) and encompasses shallow-water bodies and pronounced river channels with a total surface area of $\sim 4,892$ ha. The central axis of the wetland is defined by the main channel of the Cruces River, which is straddled by seven tributary streams affected by tidal variability - the Nanihue, Cudico, Santa María, Pichoy, Cayumapu, Tambillo and San Ramón (Fig. 1). The maximum reach of mixo-oligohaline waters $(0,5-5$ of salinity; Venice System, 1959) into the study area has been estimated to be at the confluence between Cruces River and the Cau Cau tidal channel, nearly $26 \mathrm{~km}$ upstream the outlet of the estuarine complex of the Valdivia River (Pino, 2008) (Fig. 1). The upstream area between this confluence and San Luis (SL) in the northern part of the wetland, is affected by tidal effects varying $c a$. 0.4-0.8 $\mathrm{m}$ (Pino, 2008; UACh, 2015). The CRW is characterized by relatively uniform values of the basic water characteristics (temperature, conductivity, $\mathrm{pH}$ and dissolved oxygen) (UACh, 2015) and by a notorious seasonal increase of water discharge and elevation of the water level concurrent with intense winter precipitation (Muñoz-Pedreros, 2003; UACh, 2015). The seasonal trends of precipitation, water discharge, and water levels indicate slightly higher values for these hydro-meteorological parameters during this study (2016) compared to historical averages derived from the compilation of time series of daily: precipitation data according to the meteorological station of Universidad Austral for the period 19602016, Meteorological Survey of Chile (meteorological station at Pichoy Airport, Valdivia, 1970-2016; www.meteochile.cl); water discharge and water table levels according to the electronic database of the General Water Management (Dirección General de Aguas; DGA; www.dga.cl) for the Rucaco station located $30 \mathrm{~km}$ northeast from the San Luis area (Fig. 1).

\section{Distribution and characterization of studied tidal flats}

The inventory of tidal flats in the area of the CRW was performed on March 19-20 ${ }^{\text {th }}$ of 2015 . The spatial distribution indicates higher densities and larger surface 


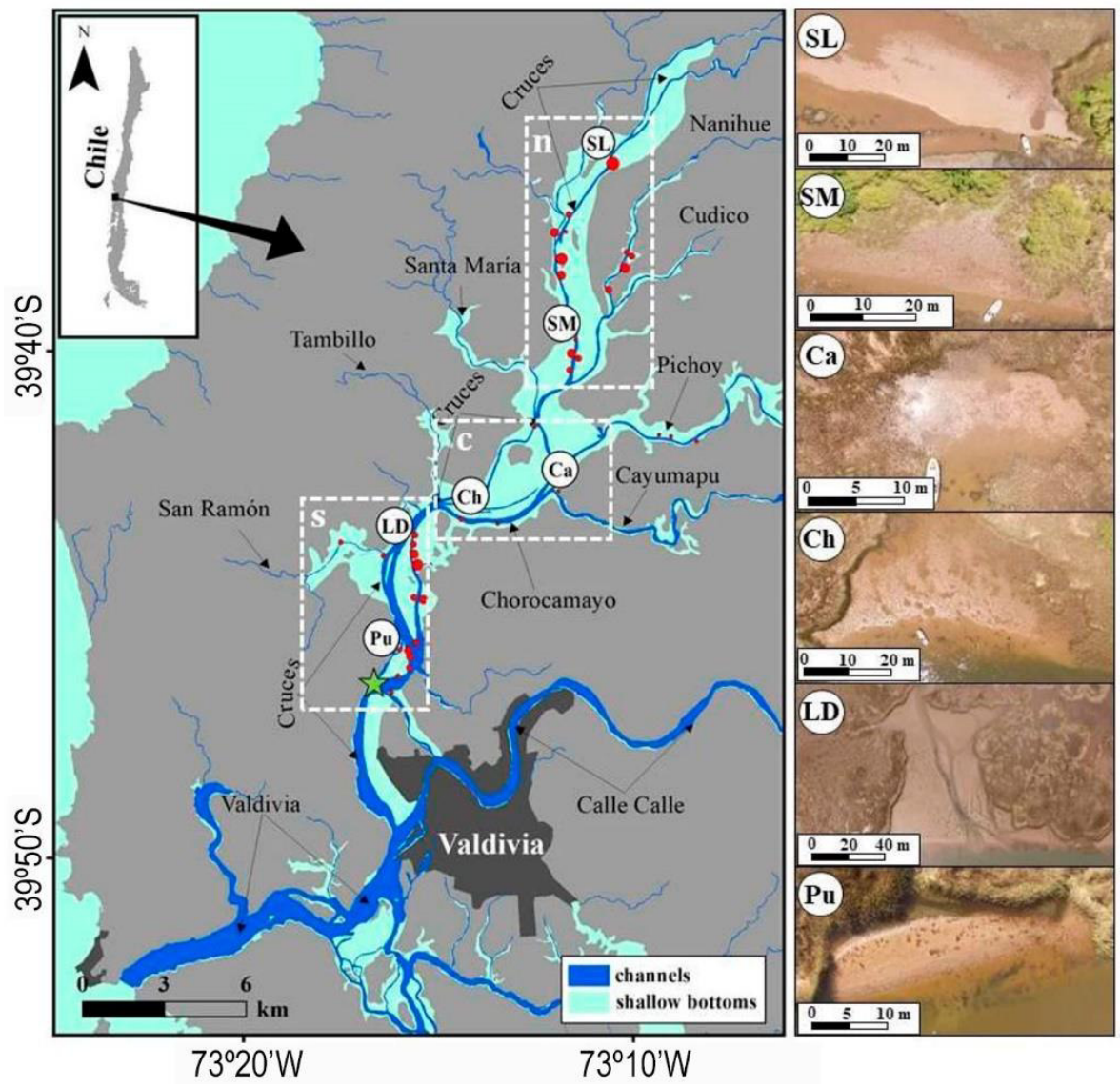

Figure 1. Location of the Cruces River wetland (CRW) in south-central Chile and the location of the most important tributary streams. The white dashed squares delimit the northern (n), central (c), and southern (s) sectors of the CRW. The red circles indicate tidal flats along the wetland, and white circles show the locations of the six studied sites (SL: San Luis, SM: Santa María, Ca: Cayumapu, Ch: Chorocamayo, LD: La Dehesa, Pu: Punucapa). The green star indicates the maximum reach of mixo-oligohaline waters (0.5-5 of salinity; Venice System, 1959) into the wetland. Zenith view aerial photographs obtained from unmanned aerial vehicles and used for the general characterization of surface and marginal environments of the studied tidal flats are presented at the right side of this figure.

areas of tidal flats in the wetland's northern and southern sectors (Fig. 1). This exploratory activity allowed us to sectorize the area in three sectors according to the grouping of tidal flats along the wetland. Later on, we choose two of them for each sector, basically in terms of landscape similarities and the absence of recent disturbances, such as the presence of artisanal docks and the influence of human activity.

Six tidal flats were randomly selected along the main Cruces River fluvial channel between San Luis in the north and Punucapa in the south (Fig. 1). From north to south, the six sites were denominated, measured, and georeferenced as follows: i) northern sector with $\mathrm{SL}=$ Cruces River, San Luis $\left(4,165 \mathrm{~m}^{2} ; 39^{\circ} 366^{\prime} 52,17^{\prime \prime} \mathrm{S}\right.$, $\left.73^{\circ} 09^{\prime} 32,71^{\prime \prime W}\right)$ and $\mathrm{SM}=$ Cruces River, Santa María $\left(1,284 \mathrm{~m}^{2} ; 39^{\circ} 40^{\prime} 14,72^{\prime \prime} \mathrm{S}, 73^{\circ} 10^{\prime} 40,58^{\prime \prime} \mathrm{W}\right)$, ii) central sector with $\mathrm{Ca}=$ confluence of Cayumapu River with Chorocamayo River (491 $\mathrm{m}^{2} ; \quad 39^{\circ} 43^{\prime} 14,66 " \mathrm{~S}$, $\left.73^{\circ} 11^{\prime} 19,94^{\prime \prime W}\right)$ and $\mathrm{Ch}=$ Chorocamayo River $(4,100$ $\mathrm{m}^{2}$; 39 $\left.43^{\circ} 43,16 " \mathrm{~S}, 7^{\circ} 13^{\prime} 52,39 " \mathrm{~W}\right)$, and iii) southern sector with LD = Cruces River, La Dehesa $\left(9,746 \mathrm{~m}^{2}\right.$; $\left.39^{\circ} 44^{\prime} 05,97^{\prime \prime} \mathrm{S}, 73^{\circ} 15^{\prime} 01,29^{\prime \prime} \mathrm{W}\right)$ and $\mathrm{Pu}=$ Cruces River, Punucapa $\left(1,123 \mathrm{~m}^{2} ; 39^{\circ} 46^{\prime} 14,57^{\prime \prime} \mathrm{S}, 73^{\circ} 15^{\prime} 29,64 " \mathrm{~W}\right)$ (Fig. 1b). Panoramic images were obtained in December 2015 with conventional cameras and unmanned aerial vehicles (drone Dji Inspire 1) to get the general features of sites, including general margin conditions and surface dimensions of tidal flats.

\section{Texture and total content of organic matter in surface sediments}

On April 8-9 $9^{\text {th }}$ and December $11^{\text {th }}, 2016$ four replicate surface sediment samples were collected at randomly selected locations -in terms of location of sampling points- along a $4 \mathrm{~m}$ strip located in the center of each site to analyze the texture (i.e., grain size fractions; 
Folk, 1974) and total organic matter content of the sediments. The analyzed material was collected from the upper surface area $(c a .2 \mathrm{~cm})$ and packed in labeled plastic bags, which were cold-stored for further laboratory analysis. The sediment texture analysis was performed according to wet sieving procedures established by Anderson et al. (1981). Portions of sediment of approximately $5 \mathrm{~g}$ each were wet sieved at 2 and $0.063 \mathrm{~mm}$ to separate the grain size fractions gravel ( $>2 \mathrm{~mm})$, sand and biogenic aggregates (2-0.063 $\mathrm{mm}$ ), and mud $(<0.063 \mathrm{~mm}$ ) (grain size according to Folk, 1974). The biogenic aggregates were mainly represented by fecal remnants and parts of mineralized tubes from annelid worms. The sand and biogenic aggregates were treated with ultrasound for $30 \mathrm{~min}$ and sieved at $0.063 \mathrm{~mm}$ to separate the sand fraction from the biogenic material, which is mainly composed of particles $<0.063 \mathrm{~mm}$ in diameter (Anderson et al., 1981). Subsequently, the grain size fractions were dried $\left(60^{\circ} \mathrm{C}\right.$ for $\left.24 \mathrm{~h}\right)$ and incinerated $\left(550^{\circ} \mathrm{C}\right.$ for $\left.6 \mathrm{~h}\right)$ to estimate the total content of organic matter in each sample (organic carboniferous or combustible matter) based on differences in weight before and after incineration (Byers et al., 1978). The colloidal suspension of mud particles $(<0.063 \mathrm{~mm})$ obtained from the second sieving step was left for decantation and subsequently leveled in 1-L test glasses. The mixture was homogenized by vertical agitation before the extraction of $20 \mathrm{~mL}$ samples with a pipette immersed at $20 \mathrm{~cm}$ from the surface. These aliquots were dried at $60^{\circ} \mathrm{C}$ for $24 \mathrm{~h}$ and subsequently incinerated at $550^{\circ} \mathrm{C}$ for $6 \mathrm{~h}$.

\section{pH and oxidation/reduction potential of surface sediments}

The $\mathrm{pH}$ and oxidation/reduction potential (ORP) of surface sediments (i.e., upper $2 \mathrm{~cm}$ ) were estimated on four replicate samples from each tidal flat. The replicates were sampled in plastic (PVC) cylinders with $4.5 \mathrm{~mm}$ of diameter, inserted into the sediment to approximately $10 \mathrm{~cm}$ depth during ebb tide, i.e., during subaerial exposure of those environments. After extraction, the cylinders were covered with lids and transported towards the sampling boat, where measurements were directly performed on an Orion Star A321 device equipped with $\mathrm{pH}$ and ORP sensors.

\section{Statistical analyses}

The spatial and temporal variability of sediment characteristics were analyzed with a permutational multivariate analysis of variance based on Euclidian distance (PERMANOVA; Anderson, 2001). This statistical method allows for the direct additive partitioning of variation, enabling tests of multivariable interactions in complex experimental setups. The statistical test - the pseudo-F parameter and its respective probability $p$ (perm.) - are calculated from a symmetric dissimilarity matrix. We calculated a distance similarity matrix from the normalized data by using dissimilarity measurements based on Euclidian distance. The PERMANOVA analysis was performed with 4999 permutations to obtain meaningful $p$ (perm.) values without leaving data unprocessed (Anderson, 2001). The tidal flats (six levels: SL, SM, Ca, Ch, LD, and $\mathrm{Pu}$ ) and the period (two levels: April and December) were considered as fixed and orthogonal factors $(n=4)$. The approximation was executed via permutations, as most of the data is not normally distributed, even after respective transformations (Anderson, 2001); only significant $(P<0.05)$ effects were tested via multiple paired comparisons, considering appropriate requisites suggested by the model (Anderson et al., 2008). We analyzed their distributions and the correlation matrix between sedimentological descriptors on the Draftsman plot (Anderson et al., 2008) to track collinearity between the applied variables. Environmental descriptors with high correlation $(\mathrm{r}>0.5)$ were excluded to avoid an excessive adjustment of variables and reduce confusion arising from associated over-estimations.

A non-metric multidimensional scaling analysis (nMDS) was used to produce two-dimensional ordination plots using Euclidian distance-based matrices of the normalized data to graphically visualize multivariate patterns among the selected sedimentological variables (mud content, pH, ORP). The comparison between sedimentological variables in tidal flats (SL, SM, Ca, $\mathrm{Ch}, \mathrm{LD}$, and $\mathrm{Pu}$ ) and months (April and December 2016) was realized with a one-way analysis of similarities (ANOSIM, Clarke, 1993). A simple regression analysis (Sokal \& Rohlf, 1995) was used to evaluate potential correlations between the average contents of mud and total organic matter and ORP values. All multivariable analyses were executed with the Primer 6.1.6. Software for statistical analysis, including the complementary package PERMANOVA. The simple regression analyses were performed with SigmaPlot 11, including the corresponding statistical extension.

\section{RESULTS}

\section{General characteristics of tidal flats}

The surface areas and outlines of tidal flats in the Cruces River wetland (CRW) are somewhat variable and generally characterized by higher frequency and larger surface areas in the northern (upstream) and southern (downstream) sectors of the wetland (Fig. 1). 
The surface area of the studied tidal flats varies between 491 and $9,756 \mathrm{~m}^{2}$ (Ca and LD, respectively; Fig. 1). The $\mathrm{SL}, \mathrm{Ca}$, and $\mathrm{Pu}$ surfaces exhibit an oval shape oriented parallel to the adjacent main water channel. The SM, $\mathrm{Ch}$, and LD surfaces have somewhat irregular, trapezoid-like shapes with their base oriented parallel to the water channel (Fig. 1). All tidal flats (except SL site) are associated with/surrounded by totora (Schoenoplectus californicus), which is the dominant macrophyte in the study region and occupies extensive $(\sim 70 \%)$ areas along their subaerial (ebb tide) perimeter (Fig. 1). The tidal flat margins verging on water channels host other widely distributed aquatic macrophytes, such as luchecillo (Egeria densa), as well as the spatially less frequent brown and green luche (Potamogeton spp.). Surface structures of biologic origin are represented by vestigial tree trunks, which are more prevalent towards the southern sector of the wetland (i.e., Ch and LD tidal flats; Fig. 1). All surfaces show micro-topographic variations, such as small trenches due to biological activity produced by wading birds and fishes and freshwater bivalves and microgrooves due to local hydraulic processes (flow and outflow currents).

\section{Texture, total organic matter content, and pH/ORP conditions in surface sediments}

\section{General aspects}

The textural features (grain size) and total organic matter contents of the analyzed sediments are summarized in Table 1 and Figures 2 and 3. The sand grain size fraction is dominant and varies between 22.2\% (LD in April) and 72.0\% (SL in December; Table 1, Fig. 2), followed by the mud fraction between 10.6-11.7\% (SL, April and December 2016, respectively) and 44.0\% (LD, April 2016) (Table 1, Fig. 2). The average percental values for biogenic aggregates vary between $17.6-33.6 \%$ and $13.7-21.3 \%$ (April and December 2016, respectively). The lowermost values (around 13\%) were estimated in December 2016 at the LD tidal flat, whereas the maxima around $30 \%$ correspond to measurements in April 2016 at the Ch and LD surfaces (Table 1, Fig. 2). The total organic matter contents lack clear trends for both sampling periods. The respective values fluctuate between 6.5 and $15.0 \%$ in April, and 7.7 and $14.1 \%$ in December 2016 (Table 1, Fig. 3).

The $\mathrm{pH}$ and ORP values of surface sediments estimated in April and December 2016 demonstrate significant variability for most of the sites. For example, the $\mathrm{pH}$ values for April/December are below/above the overall average (SL and SM tidal flats; Fig. 4, Table 2). The general trend of all ORP values and those estimated for individual sites varies signifi- cantly between April and December. Furthermore, the variability between different sites was less strong and with positive values (increased oxidation conditions in the sediment) in April. December yielded most of the ORP negative values (SM and Ch sediments; Fig. 4).

Due to the high correlation between textural variables (grain size) and the total organic matter content (Draftsman plot; Anderson et al., 2008), the multivariable statistical analysis was restricted to the mud fraction, along with the $\mathrm{pH}$ and ORP factors. Table 3 summarizes the variance analyses via permutations (PERMANOVA; Anderson et al., 2008) for mud, pH, and ORP between and within the different tidal flats. The comparison of mud contents between surfaces $(\mathrm{P})$ yielded showed significant differences $(P<0.05)$. In contrast, the temporal variability (M, April vs. December) of this grain size fraction, as well as the interaction between its percental fraction among different tidal flats and months $(\mathrm{P} \times \mathrm{M})$, were nonsignificant $(P>0.05)$. In turn, the evaluation of potential differences in $\mathrm{pH}$ values between tidal flats and sampling months yielded significant differences $(P$ $<0.05$ ) only for the source of interactions between these factors $(\mathrm{P} \times \mathrm{M})$. Finally, the ORP analysis indicates significant differences $(P<0.05)$ between tidal flats and months, as well as for the interaction between these factors (Table 3). The spatial variability of the ORP vs. the content of mud and total organic matter demonstrates significantly lower or negative ORP values in samples with a higher content of mud and organic matter (Fig. 5).

The nmMDS analysis was performed to graphically visualize possible group patterns between replicate samples according to variable mud contents, $\mathrm{pH}$, and ORP conditions, and considering a general division of the CRW in northern, central, and southern sector (Fig. 6). A notorious spatial clustering was observed for April 2016 between replicate samples from tidal flats in the northern CRW sector (i.e., SL and SM). This pattern differs from the larger graphical distance between replicate samples within each sector during December 2016 (Fig. 6). The stress values from each analysis $(<0.1)$ indicate good-to-acceptable graphical representation (Kruskal, 1964) of the differences and similarities between the studied tidal flats.

\section{DISCUSSION}

The 1960 Valdivia earthquake generated co-seismic continental subsidence, which caused the widening and deepening of extensive areas around the mainstream channel of the Cruces River. Wide areas along the river banks transformed into shallow-water bodies with reduced bottom slope, which are frequently influenced 
Table 1. Average percentage values for sand, mud, biogenic aggregates, and total organic matter contents in surface sediments on the studied tidal flats (Fig. 1) during April and December 2016. The average/error is based on four replicate samples and their standard deviation SL: San Luis, SM: Santa María, Ca: Cayumapu, Ch: Chorocamayo, LD: La Dehesa, Pu: Punucapa.

\begin{tabular}{|c|c|c|c|c|c|c|c|c|}
\hline \multirow{2}{*}{ Sites } & \multicolumn{2}{|c|}{ Sand } & \multicolumn{2}{|c|}{ Mud } & \multicolumn{2}{|c|}{ Biogenic aggregates } & \multicolumn{2}{|c|}{ Total organic matter } \\
\hline & April & December & April & December & April & December & April & December \\
\hline SL & $68.7(6.8)$ & $72.0(8.7)$ & $10.6(3.9)$ & $11.7(2.8)$ & $19.8(5.1)$ & $16.4(6.7)$ & $7.9(1.7)$ & $9.3(3.2)$ \\
\hline SM & $46.9(25.9)$ & $47.6(11.7)$ & $24.1(13.6)$ & $31.0(9.2)$ & $28.9(13.4)$ & $21.3(7.5)$ & $12.9(4.4)$ & $14.1(1.6)$ \\
\hline $\mathrm{Ca}$ & $47.3(14.1)$ & $60.4(12.9)$ & & & & & $10.3(2.3)$ & $8.0(1.2)$ \\
\hline $\mathrm{Ch}$ & $35.8(8.8)$ & $53.2(6.3)$ & $30.6(5.2)$ & $31.7(4.7)$ & $33.6(4.5)$ & $15.1(2.2)$ & $10.6(3.0)$ & $9.1(0.7)$ \\
\hline LD & $22.2(6.5)$ & $57.5(11.4)$ & $44.0(1.7)$ & $28.7(6.3)$ & $33.6(5.4)$ & $13.7(6.0)$ & $15.0(1.0)$ & $7.7(1.2)$ \\
\hline $\mathrm{Pu}$ & $63.1(17.8)$ & $61.1(16.5)$ & $19.2(10.4)$ & $23.6(9.4)$ & $17.6(7.4)$ & $15.1(7.3)$ & $6.5(2.7)$ & $10.0(3.4)$ \\
\hline
\end{tabular}

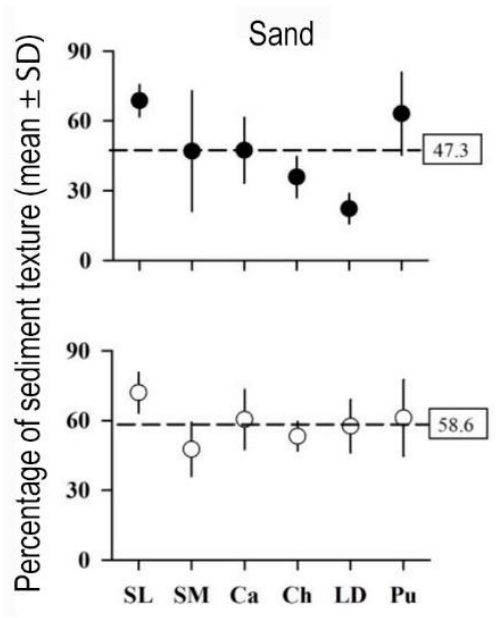

- April 2016
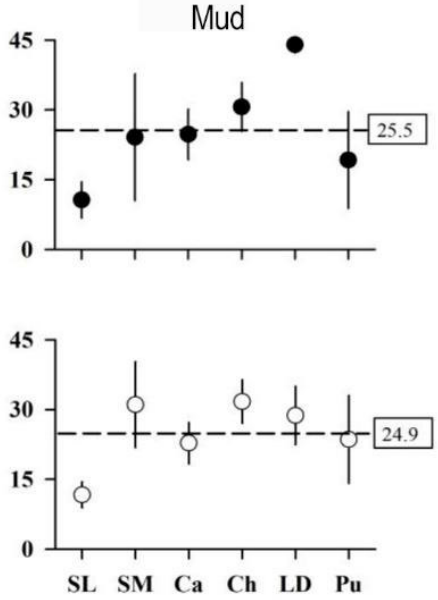

Studied sites
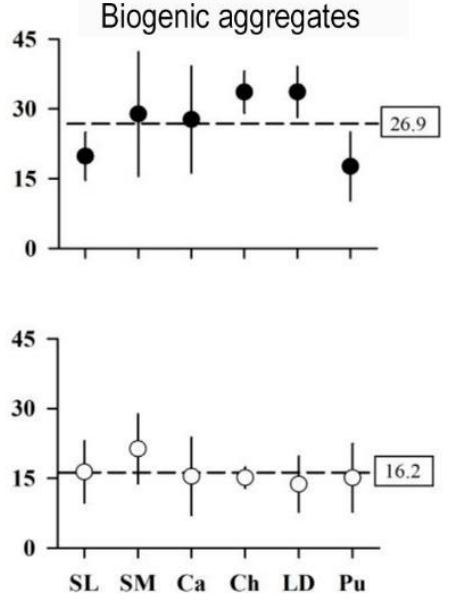

Figure 2. Spatial-temporal (April and December 2016) variability of sediment texture for the six studied tidal flats (see Fig. 1).The white rectangles display the total average values (stippled black line) based on measurements from all tidal flats.

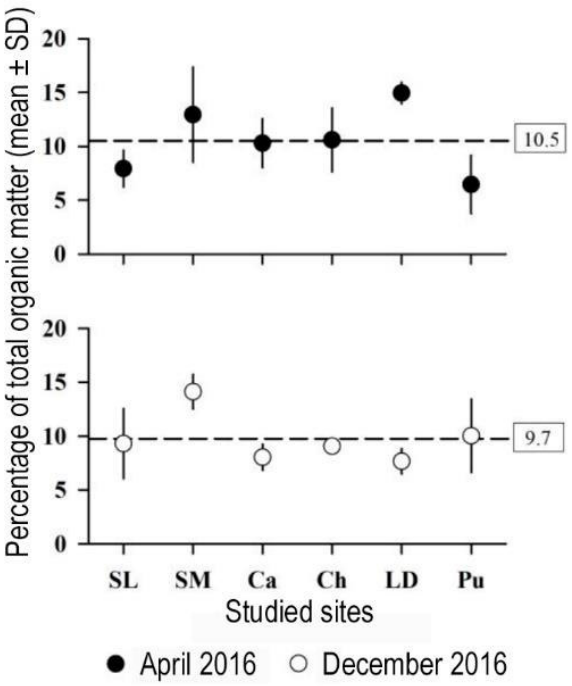

Figure 3. Spatial-temporal (April and December 2016) variability of total organic matter contents for the six studied tidal flats (see Fig. 1). The white rectangles display the total average values (stippled black line) based on measurements from all tidal flats. by tidal currents. These environmental characteristics likely promoted the processes and dynamics of sedimentation and evolution of the present tidal flats in the wetland. Similar circumstances have been reported from nearby areas, such as the estuaries of the rivers Lingue and Queule located approximately $50 \mathrm{~km}$ to the north of CRW (Saint Amand, 1961; Pino \& Mulsow, 1983; Pino et al., 1999).

The tidal flat surfaces in CRW are characterized by considerable variability considering their shape and size. They are generally associated with extensive areas covered with Schoenoplectus californicus (totora) and Spartina densiflora (commonly known as espartina), which are assigned a major ecological value, because of their fundamental role as environmental engineers. These macrophyte species, model and stabilize the wetland shores against external hydraulic stress factors (Valdovinos et al., 2010), and capture suspended material in their canopy structures (Madsen et al., 2001; Bouma et al., 2005; Leonard \& Croft, 2006; Anthony, 2008; Ma et al., 2014). Therefore, the occurrence and 

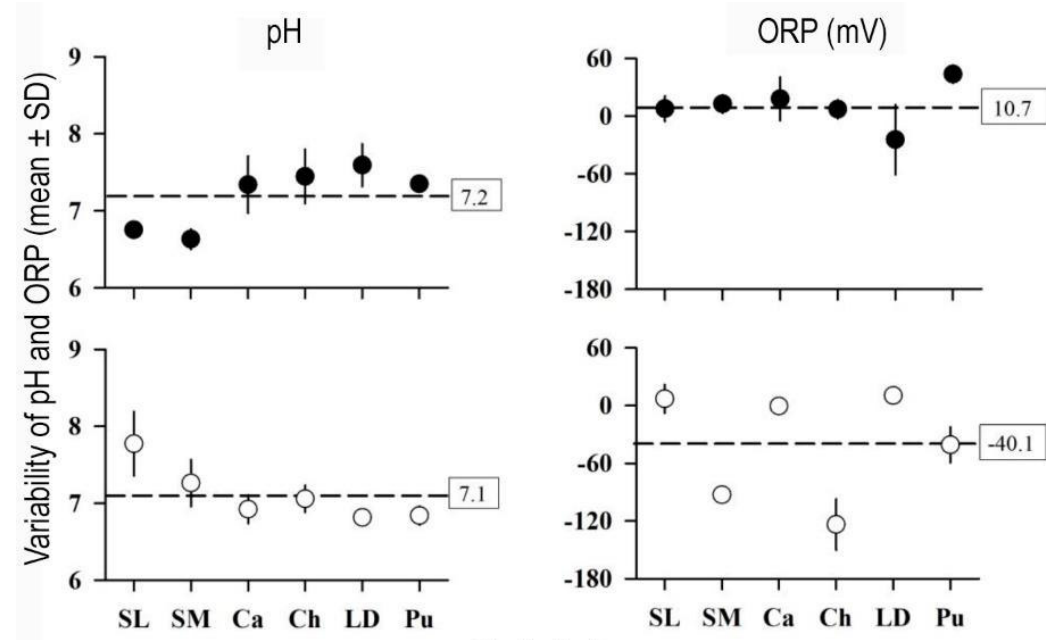

Studied sites

- April 2016 O December 2016

Figure 4. Spatial-temporal (April and December 2016) variability of $\mathrm{pH}$ and ORP (mV) values for the six studied tidal flats (Fig. 1). The white rectangles display the total average values (stippled black line) based on measurements from all tidal flats.

Table 2. Average values of $\mathrm{pH}$ and oxidation/reduction potential (ORP in $\mathrm{mV}$ ) of surface sediments on the studied tidal flats during April and December (see Fig. 1). The average values/errors are based on four replicate samples and their standard deviation.

\begin{tabular}{lccccc}
\hline \multirow{2}{*}{ Sites } & \multicolumn{2}{c}{$\mathrm{pH}$} & & \multicolumn{2}{c}{ ORP $(\mathrm{mV})$} \\
\cline { 2 - 3 } \cline { 5 - 6 } & April & December & & April & December \\
\hline SL & $6.8 \pm 0.1$ & $7.8 \pm 0.4$ & & $7.6 \pm 13.1$ & $7.0 \pm 14.8$ \\
SM & $6.6 \pm 0.1$ & $7.3 \pm 0.3$ & & $12.6 \pm 9.5$ & $-92.8 \pm 7.7$ \\
Ca & $7.3 \pm 0.4$ & $6.9 \pm 0.2$ & & $17.8 \pm 22.5$ & $-0.6 \pm 7.7$ \\
Ch & $7.4 \pm 0.4$ & $7.1 \pm 0.2$ & & $7.0 \pm 9.7$ & $-123.7 \pm 26.4$ \\
LD & $7.6 \pm 0.3$ & $6.8 \pm 0.1$ & & $-24.6 \pm 36.3$ & $10.4 \pm 4.9$ \\
Pu & $7.3 \pm 0.0$ & $6.8 \pm 0.1$ & & $43.5 \pm 9.3$ & $-40.8 \pm 18.4$ \\
\hline
\end{tabular}

spatial distribution of totora might be favoring the formation and maintenance of tidal flats in the wetland as well.

The majority and largest tidal flat environments are concentrated in the northern and southern sectors of the CRW. This spatial distribution might be the result of differential co-seismic subsidence during the 1960 earthquake, controlled by the location and different orientation of geological fault structures (SERNAGEOMIN, 2004) responsible non-uniform block movements (Illies, 1970). This scenario would imply differential subsidence and spatially variable magnitudes of sediment accumulation. The nonuniform distribution of tidal flats might also be determined by the variable occurrence of aquatic macrophytes such as luchecillo (Egeria densa) -a species that colonizes shallow-water environments and promotes the stabilization and catching of suspended particles from the water column (Yarrow et al., 2009; Redekop et al., 2016).

The sediments of the studied tidal flats sediments are characterized by the high concentrations of sand particles, a situation probably linked to the high concentration of suspended material in the water column related to higher velocities of the tidal currents during the inflow of the tidal wave into shallow waters. The resulting flow increase of the rising tide is then an order of magnitude higher than the flow generated by the natural drainage of the Cruces River (UACh, 2015). The sand/mud textural ratio observed in this study is coherent with results obtained from similar environments in the estuaries of Lingue River and Queule River, which host wetlands of similar tectonic origin to CRW (see, for example, Bertrán, 1984; Richter, 1985: Quijón \& Jaramillo, 1996; Pino et al., 1999; Jaramillo et al., 2001).

The fraction of mud content varies significantly $(P$ $<0.05$ ) between tidal flats, but less so between sampling periods. During the early-fall sampling (April 2016), the surface sediments showed greater variability, with strikingly high mud contents in the $\mathrm{La}$ Dehesa surface. The latter might be related to the increased density of vestigial tree trunks in this particular tidal flat, which might potentially modify the local hydrodynamic conditions and the deposition of fine sediments. In turn, sampling during the spring of 2016, indicated higher textural, between sediments from 
Table 3. Summary of two-way PERMANOVA analysis to evaluate possible differences in the mud grain size fraction, $\mathrm{pH}$, and ORP values in tidal flat sediments. The bold $p($ perm. $)$ values are significant $(P<0.05)$ for each test. dl: degree of freedom, SC: sum of squares, MS: mean squares.

\begin{tabular}{llcrrrc}
\hline Parameter & \multicolumn{1}{c}{ Source } & $\mathrm{dl}$ & \multicolumn{1}{c}{$\mathrm{SC}$} & $\mathrm{MS}$ & pseudo-F & $p$ (perm. \\
\hline Mud & Tidal flat (T) & 5 & 25.81 & 5.16 & 11.62 & $\mathbf{0 . 0 0 0 2}$ \\
& Month (M) & 1 & 0.04 & 0.04 & 0.09 & 0.7696 \\
& $\mathrm{~T} \times \mathrm{M}$ & 5 & 5.16 & 1.03 & 2.32 & 0.0686 \\
& Error & 36 & 15.99 & 0.44 & & \\
& Total & 47 & 47 & & & \\
\hline $\mathrm{pH}$ & Tidal flat (T) & 5 & 3.34 & 0.67 & 1.88 & 0.1242 \\
& Month (M) & 1 & 0.37 & 0.37 & 1.05 & 0.3118 \\
& $\mathrm{~T} \times \mathrm{M}$ & 5 & 30.54 & 6.11 & 17.24 & $\mathbf{0 . 0 0 0 2}$ \\
& Error & 36 & 12.75 & 0.35 & & \\
& Total & 47 & 47 & & & \\
\hline ORP & Tidal flat (T) & 5 & 12.63 & 2.53 & 20.39 & $\mathbf{0 . 0 0 0 2}$ \\
& Month (M) & 1 & 12.54 & 12.54 & 101.24 & $\mathbf{0 . 0 0 0 2}$ \\
& T $\times$ M & 5 & 17.38 & 3.48 & 28.06 & $\mathbf{0 . 0 0 0 2}$ \\
& Error & 36 & 4.46 & 0.13 & & \\
& Total & 47 & 47 & & & \\
\hline
\end{tabular}

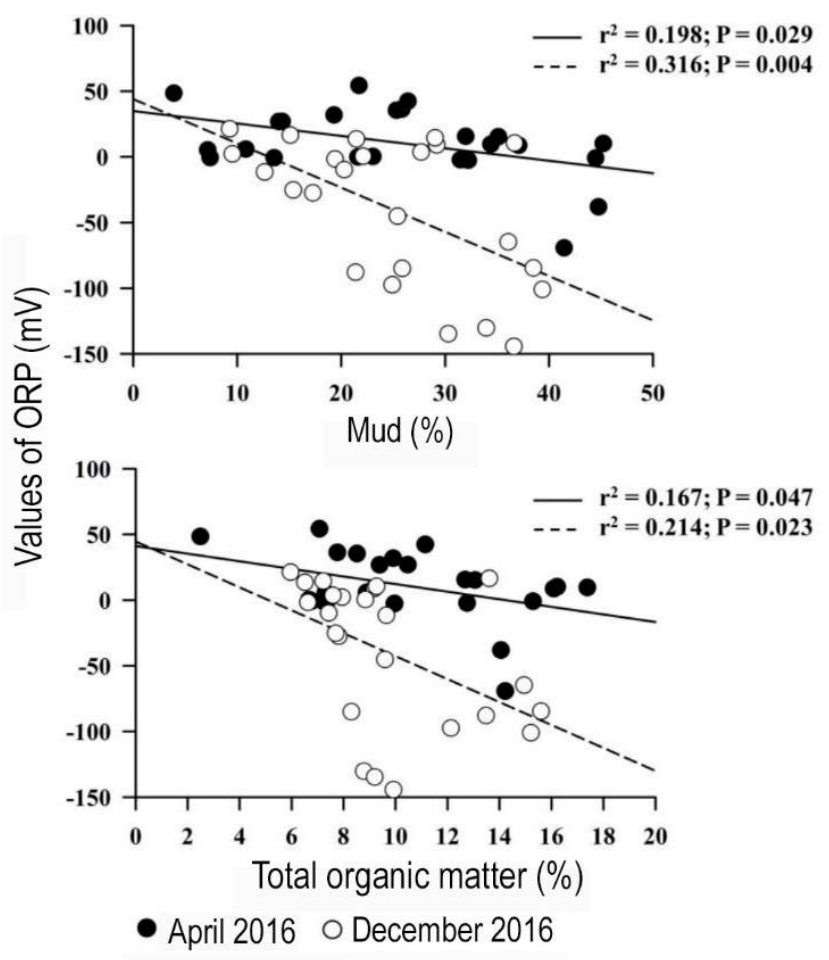

Figure 5. Variability of ORP values against mud and total organic matter contents in the sediments studied (samples from all tidal flats are included).

different tidal flats that could be related to higher fluvial channel discharge during winter (due to intense precipitation), which is then expected to affect the local distribution and characteristics of surface sediments (Rojas, 1984; Bertrán, 1989; Jaramillo et al., 2001). This hypothesis is also coherent with the increased fraction of sandy material on all studied tidal flats. The seasonal variability of fluvial discharge might also be correlated with the observed low concentration of biogenic aggregates in December, which are expected to be more easily destroyed by physical perturbations such as stronger tidal currents (Bertrán, 1984; Richter, 


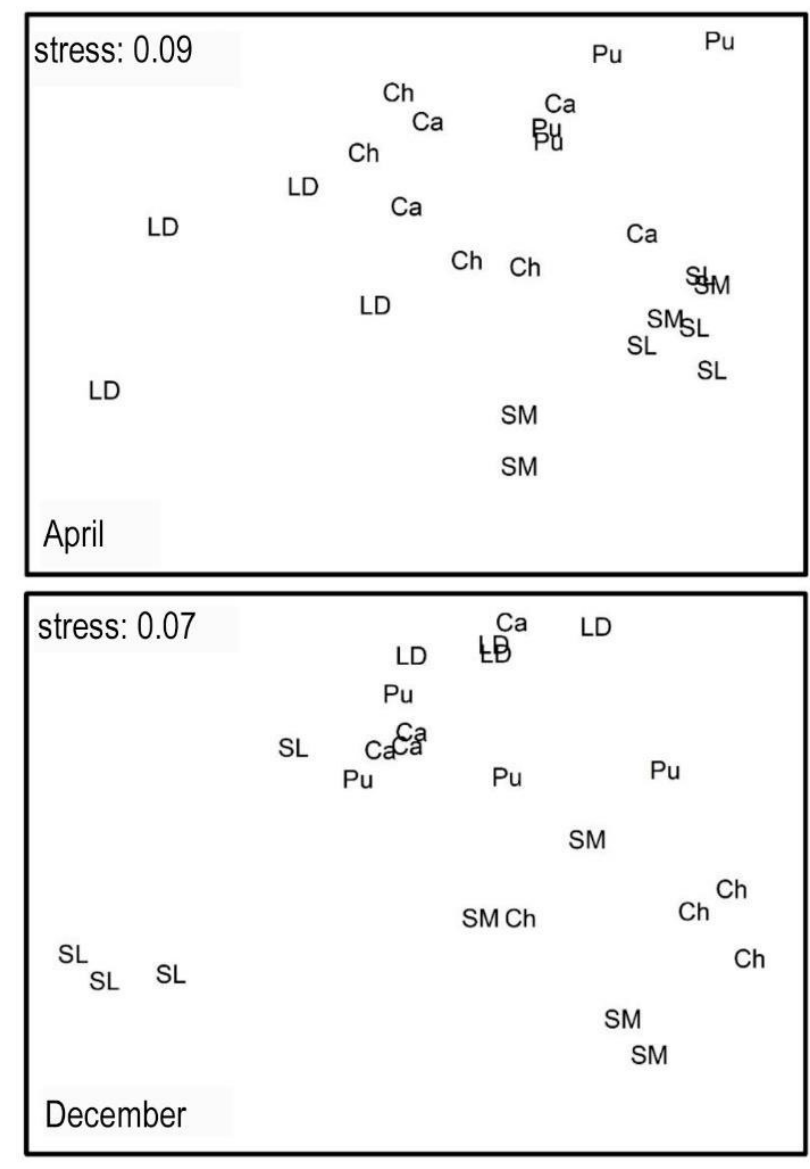

Figure 6. Graphical representation of results from the nMDS analysis based on normalized Euclidean distance and representing the spatial (between tidal flats; Fig. 1) and temporal (April and December 2016) variability of mud contents and $\mathrm{pH} / \mathrm{ORP}$ values.

1985: Quijón \& Jaramillo, 1996; Pino et al., 1999; Jaramillo et al., 2001).

Nonetheless, the total content of organic matter in the sediments is not correlated with seasonal fluctuations of fluvial discharge. They showed similar values during both sampling periods and between studied tidal flats. Similarly, $\mathrm{pH}$ conditions of surface sediments were close to neutral ( 7), both before and after the intense winter precipitations, and are not affected by those.

The spatio-temporal variability of ORP conditions is coupled to the contents of mud and total organic matter in the sediments (i.e., total organic matter; Madsen et al., 2001; Atapaththu et al., 2017). In turn, it might be associated with the seasonal climatic variability indicated by slightly positive values in April vs. December 2016. This ORP variability might be attributed to the biological activity of the generally abundant macro-infauna in the intertidal environment of the studied surfaces (Quijón \& Jaramillo, 1993,
1996). Various studies have demonstrated the capacity of numerous invertebrate species representing the macro-infauna of tidal flats to modify the grain size of sediments and produce bioturbation on the surfaces of this type of coastal environments (Anderson, 1983; Perillo, 2003; Satish \& Bhawanisingh, 2009).

These results, combined with the graphical analyses (nMDS), indicate notoriously different surface sediments features from the northern sector for the fall sampling period, compared to the rest of the CRW (i.e., San Luis and Santa María. In turn, spring sampling indicates only minor differential group patterns between sites or sectors, which show a rather uniform distribution of mud contents and $\mathrm{pH}$ conditions. This more uniform distribution might be assigned to the physical effects of increased water discharge during the winter, which is expected to influence spatial distribution and characteristics of surface sediments (Rojas, 1984; Bertrán, 1989; Jaramillo et al., 2001). Such homogenization is typical for other coastal sedimentary environments exposed to periodic physical perturbations, such as swells, tidal waves, or punctual events such as tsunamis (Sasaki et al., 1995; Jaramillo et al., 2012; Abe et al., 2016).

\section{CONCLUSIONS}

Although sedimentary features of the Cruces River wetland's tidal flats show seasonal variability, the texture of sediments and organic matter content remained quite similar along the study period, with sand particles $(63-2,000 \mu)$ as the dominant fraction. Since our results are the first ones for this Ramsar site, the same should be considered as a primary tool for further scientific studies, dealing, for example, with temporal variability of sedimentary features associated with climate change. As such, those results will be useful to design management strategies aimed to cope not only with future risk scenarios linked to that environmental forcing, but also with an increased modification of wetland margins by urban expansion, forestry, and industrial activities, which could modify sediment structure along with the water-land interface. Thus, this study's outcome could be further implemented into the public policy-making related to the strategic management of coastal wetlands in southcentral Chile.

\section{ACKNOWLEDGMENTS}

This study was funded by the service contract ARAUCO \& UACh (Environmental Monitoring Program of the Río Cruces wetland and its tributary systems 2015-2020). M.M. thanks CONICYT (Natio- 
nal Commission for Scientific and Technological Research) for supporting grant 21130203 from the National Doctoral Scholarships and Operational Costs program.

\section{REFERENCES}

Abe, H., Kobayashi, G. \& Sato-Okoshi, W. 2016. Ecological impacts of the great east Japan earthquake and tsunami and the following succession on the subtidal macrobenthic community in Onagawa Bay, northeastern Japan, with special reference to the dominant taxon, Polychaetes. In: Urabe, J. \& Nakashizuka, T. (Eds.). Ecological impacts of tsunamis on coastal ecosystems: lessons from the great east Japan earthquake. Springer, Berlin, pp. 59-84.

Anderson, F., Black, L., Mayer, L. \& Watling, L. 1981. A temporal and spatial study of mudflat texture. North Eastern Geology, 3: 184-196.

Anderson, M., Gorley, R. \& Clarke, K. 2008. PERMANOVA+ for PRIMER: guide to software and statistical methods. PRIMER-E, Plymouth.

Anderson, F.E. 1983. The northern muddy intertidal: seasonal factors controlling erosion and deposition - a review. Canadian Journal of Fisheries and Aquatic Sciences, 40: 143-159.

Anderson, M.J. 2001. A new method for non-parametric multivariate analysis of variance. Austral Ecology, 26: 32-46.

Anthony, E.J. 2008. Shore processes and their palaeoenvironmental applications. Developments in Marine Geology. Elsevier, Amsterdam.

Atapaththu, K.S.S., Asaeda, T., Yamamuro, M. \& Kamiya, H. 2017. Effects of water turbulence on plant, sediment, and water quality in reed (Phragmites australis) community. Ekológia, 36(1): 1-9.

Bagdanaviciute, I., Kelpsaite, L. \& Soomere, T. 2015. Multi-criteria evaluation approach to coastal vulnerability index development in micro-tidal lowlying areas. Ocean \& Coastal Management, 104: 124135.

Barbier, E.B., Hacker, S.D., Kennedy, C., Koch, E.W., Stier, A.C. \& Silliman, B.R. 2011. The value of estuarine and coastal ecosystem services. Ecological Monographs, 81(2): 169-193.

Bertrán, C. 1984. Macroinfauna Intermareal en un estuario del sur de Chile (estuario del Río Lingue, Valdivia). Studies on Neotropical Fauna and Environment, 19: 33-46.

Bertrán, C. 1989. Zonación y dinámica temporal de la macroinfauna intermareal en el estuario del Río Lingue (Valdivia, Chile). Revista Chilena de Historia Natural, 62: 19-32.
Bouma, T.J., de Vries, M.B., Low, E., Peralta, G., Tanczos, C., van de Koppel, J. \& Herman, P.M.J. 2005. Trade-offs related to ecosystem engineering: a case study on stiffness of emerging macrophytes. Ecology, 86: 2187-2199.

Byers, S., Mills, E. \& Steward, P. 1978. A comparison of methods of determining organic carbon in marine sediments, with suggestion for a standard method. Hydrobiologia, 58: 43-47.

Clarke, K.R. 1993. Non-parametric multivariate analyses of changes in community structure. Australian Journal of Ecology, 18: 117-143.

DeMets, C., Gordon, R.G., Argus, D.F. \& Stein, S. 1990. Current plate motions. Geophysical Journal International, 101: 425-478.

Escaida, J., Jaramillo, E., Amtmann, C. \& Lagos, N. 2014. Crisis socioambiental: el humedal del Río Cruces y el cisne de cuello negro. Ediciones UACh, Valdivia.

Fariña, J. \& Camaño, A. 2012. Humedales costeros de Chile: aportes científicos a su gestión sustentable. Ediciones Universidad Católica de Chile, Santiago.

Folk, R.L. 1974. Petrology of sedimentary rocks. Hemphill Publishing Company, Texas.

González, A.L. \& Fariña, J.M. 2013. Changes in the abundance and distribution of black-necked swans (Cygnus melancoryphus) in the Carlos Anwandter Nature Sanctuary and adjacent wetlands, Valdivia, Chile. Waterbirds, 36: 507-514.

Healy, T., Wang, Y. \& Healy, J. 2002. Muddy coasts of the world: processes, deposits, and function. Elsevier Science, Amsterdam.

Illies, H. 1970. Geología de los alrededores de Valdivia y volcanismo y tectónica en márgenes del Pacífico en Chile meridional. Universidad Austral de Chile, Valdivia.

Jaramillo, E., Contreras, H. \& Quijón, P. 2001. Seasonal and interanual variability in population abundances of the intertidal macrofauna of Queule River estuary, south-central Chile. Revista Chilena de Historia Natural, 74: 455-468.

Jaramillo, E., Contreras, H. \& Duarte, C. 2007. Community structure of the macrofauna inhabiting tidal flats characterized by the presence of different species of burrowing bivalves in southern Chile. Hydrobiologia, 580: 85-96.

Jaramillo, E., Dugan, J.E., Hubbard, D.M., Melnick, D., Manzano, M., Duarte, C., Campos, C. \& Sánchez, R. 2012. Ecological implications of extreme events: footprints of the 2010 earthquake along the Chilean coast. Plos One, 7(5). doi: 10.1371/journal.pone. 0035348 
Koh, C.H. \& Khim, J.S. 2014. The Korean tidal flat of the yellow sea: physical setting, ecosystem and management. Ocean \& Coastal Management, 102: 398-414.

Kruskal, J.B. 1964. Non-metric multidimensional scaling: a numerical method. Psychometrika, 2: 115-129.

Lagos, N.A., Paolini, P., Jaramillo, E., Lovengreen, C., Duarte, C. \& Contreras, H. 2008. Environmental processes, water quality degradation, and decline of waterbird populations in the Río Cruces wetland, Chile. Wetlands, 28: 938-950.

Leonard, L.A. \& Croft, A.L. 2006. The effect of standing biomass on flow velocity and turbulence in Spartina alterniflora canopies. Estuarine, Coastal and Shelf Science, 69: 325-336.

Ma, G., Han, Y., Niroomandi, A., Lou, S. \& Liu, S. 2014. Numerical study of sediment transport on a tidal flat with a patch of vegetation. Ocean Dynamics, 65: 203222.

Marín, V.H., Tironi, A., Delgado, L.E., Contreras, M., Novoa, F., Torres-Gómez, M., Garreaud, R., Vila, I. \& Serey, I. 2009. On the sudden disappearance of Egeria densa from a Ramsar wetland site of southern Chile: a climatic event trigger model. Ecological Modelling, 220: 1752-1763.

Madsen, J.D., Chambers, P.A., James, W.F., Koch, E.W. \& Westlake, D.F. 2001. The interaction between water movement, sediment dynamics and submersed macrophytes. Hydrobiologia, 444: 71-84.

Miththapala, S. 2013. Tidal flats. Coastal ecosystems series, vol. 5. IUCN, Colombo.

Murray, N.J., Ma, Z. \& Fuller, R. 2015. Tidal flats of the yellow sea: a review of ecosystem status and anthropogenic threats. Austral Ecology, 40: 472 -481.

Muñoz-Pedreros, A. 2003. Guía de los humedales del Río Cruces. CEA Ediciones, Valdivia.

Niering, R. 1985. Wetlands. Alfred A. Knopf, New York.

Neira, C., Grosholz, E., Levin, L. \& Blake, R. 2006. Mechanisms generating modification of benthos following tidal flat invasion by a spartina hybrid. Ecological Applications, 16: 1391-1404.

Palma, A.T.C., Schwarz, A.O. \& Farina, J.M. 2013. Experimental evidence of the tolerance to chlorate of the aquatic macrophyte Egeria densa in a Ramsar wetland in southern Chile. Wetlands, 33: 129-140.

Perillo, G. 2003. Dinámica del transporte de sedimentos. Asociación Argentina de Sedimentología, Buenos Aires.

Pinochet, D., Ramírez, C., MacDonald, R. \& Riedel, L. 2005. Concentraciones de elementos minerales en Egeria densa Planch, colectados en el santuario de la naturaleza Carlos Anwandter, Valdivia, Chile. Agro Sur, 32(2): 80-86.
Pino, M. 1994. Geomorfología, sedimentología y dinámica de la circulación en estuarios micro mareales del centro sur de Chile. Resumen XIV Jornadas de Ciencias del Mar, Puerto Montt, pp. 106-107.

Pino, M. 2008. Determinación de la posición de la cabecera del estuario del Río Cruces, Región de Los Ríos, Chile. Comisión Nacional del Medio Ambiente (CONAMA), Santiago.

Pino, M. \& Mulsow, S. 1983. Distribución de facies granulométricas en el estuario del Río Queule, IX Región: un análisis de componentes principales. Andean Geology, 18: 77-85.

Pino, M., Busquets, T. \& Brümmer, R. 1999. Temporal and spatial variability in the sediments of a tidal flat, Queule river estuary, south-central Chile. Andean Geology, 26: 187-204.

Plafker, G. \& Savage, J. 1970. Mechanism of the Chilean earthquakes of May 21 and 22, 1960. Geological Society of America Bulletin, 81: 1001-1030.

Quijón, P. \& Jaramillo, E. 1993. Temporal variability in the intertidal macroinfauna in the Queule River Estuary, south-central Chile. Estuarine, Coastal and Shelf Science, 37: 655-667.

Quijón, P. \& Jaramillo, E. 1996. Seasonal vertical distribution of the intertidal macrofauna in an estuary of south-central Chile. Estuarine, Coastal and Shelf Science, 43: $653-663$.

Ramírez, C., Carrasco, E., Mariani, S. \& Palacios, N. 2006. La desaparición del luchecillo (Egeria densa) del santuario del Río Cruces (Valdivia, Chile): una hipótesis plausible. C\&T, 20: 79-86.

Ramírez, C., San Martín, C., Medina, R. \& Contreras, D. 1991. Estudio de la flora hidrófila del santuario de la naturaleza Río Cruces (Valdivia, Chile). Gayana Botánica, 48: 64-80.

Redekop, P., Hofstra, D. \& Hussner, A. 2016. Elodea canadensis shows a higher dispersal capacity via fragmentation than Egeria densa and Lagarosiphon major. Aquatic Botany, 130: 45-49.

Reise, K. 1985. Tidal flat ecology: an experimental approach to species interaction. Springer-Verlag, New York.

Reise, K., Baptist, M., Burbridge, P., Dankers, N., Fischer, L., Flemming, B., Oost, A.P. \& Smit, C. 2010. The Wadden Sea - a universally outstanding tidal wetland. Wadden Sea Ecosystem, 29. Common Wadden Sea Secretariat, Wilhelmshaven.

Richter, W. 1985. Distribution of the soft-bottom macrofauna in an estuary of southern Chile. Marine Biology, 86: 93-100.

Rojas, C. 1984. Estudio estacional de los sedimentos del Estuario del Queule, IX Región. Informaciones Geográficas, 31: 55-65. 
Saint Amand, P. 1961. Observaciones e interpretación de los terremotos chilenos de 1960. Ediciones Universidad de Chile, Santiago.

San Martín, C., Medina, R., Ojeda, P. \& Ramírez, C. 1993. La biodiversidad vegetacional del santuario de la naturaleza "Río Cruces" (Valdivia, Chile). Acta Botánica Malacitana, 18: 259-279.

Sasaki, K., Aoyagi, K. \& Arai, N. 1995. Bottom sediments of Onagawa Bay, Miyagi. Bulletin of the Japanese Society of Fisheries Oceanography, 59: 241-249.

Satish, J.P. \& Bhawanisingh, G.D. 2009. Animalsediment relationship of the crustaceans and polychaetes in the intertidal zone around Mandvi, Gulf of Kachchh, Western India. Journal of the Geological Society of India, 74: 233-259.

Servicio Nacional de Geología y Minería (SERNAGEOMIN). 2004. Mapa geológico de Chile: versión digital. Servicio Nacional de Geología y Minería, Santiago.

Sokal, R. \& Rohlf, F. 1995. Biometry the principles and practice of statistics in biological research. W.H. Freeman, New York.

Schlatter, R.P., Navarro, R.A. \& Corti, P. 2002. Effects of El Niño southern oscillation on numbers of blacknecked swans at Río Cruces Sanctuary, Chile. Waterbirds, 25(1): 114-122.

Schlatter, R., Salazar, J., Villa, A. \& Meza, J. 1991. Reproductive biology of black-necked swans Cygnus melancoryphus at three Chilean wetland areas and feeding ecology at Río Cruces. Wildfowl, 1: 268-271.

Schaefer, K. \& Einax, W. 2010. Analytical and chemometric characterization of the Cruces River in south Chile. Environmental Science and Pollution Research, 17: 115-123.

Received: 22 May 2019; Accepted: 26 May 2020
Thom, R.M., Blanton, S.L., Woodruff, D.L., Williams, G.D. \& Borde, A.B. 2001. Carbon sinks in nearshore marine vegetated ecosystems. Proceedings of First National Conference on Carbon Sequestration, 14-17 May 2001. The National Energy Technology Laboratory (NETL), Morgantown.

Universidad Austral de Chile (UACh). 2015. Programa de diagnóstico ambiental del humedal del Río Cruces y sus ríos tributarios: 2014-2015. Informe Final, Universidad Austral de Chile, Valdivia.

Valdovinos, C., Dolores, M., Sandoval, N., Vásquez, D. \& Olmos, V. 2010. Desastres naturales y biodiversidad: el caso del humedal costero Tubul-Raqui. Sociedad Hoy, 19: 33-51.

Venice System, 1959. Final resolution of symposium on the classification of brackish-waters. Archo Oceanography Limnology, 11(1): 243-245.

Woelfl, S., Mages, M., Encina, F. \& Bravo, F. 2006. Trace metals in microcrustaceans and Brazilian waterweed from a contaminated Chilean wetland using total reflection x-ray fluorescence spectrometry. Microchimica Acta, 3: 261-268.

Yarrow, M., Marín, V.H., Finlayson, M., Tironi, A., Delgado, L.E. \& Fischer, F. 2009. The ecology of Egeria densa Planch. (Liliopsida: Alismatales): a wetland ecosystem engineer? Revista Chilena de Historia Natural, 82: 299-213. 